\title{
Characterization of Silver Powder Produced through Water Atomization and RF Plasma Treatment
}

\author{
Shigehiro Arita, Takashi Ogihara*, Toshihiko Kubo, Yasuhiro Tsubota, Kenji Ohshita, Nobuyoshi Aoyagi, Ryosuke \\ Ueyama, Masahiro Harada and Akio Harada \\ Daiken Chemical Sales \& Mfg Co., Ltd,1-3-3 Technoport, Mikuni-cho, Sakai-shi, Fukui, 913-0038, Japan
}

\begin{abstract}
Silver powder was produced through water atomization with a pressure of $80 \mathrm{MPa}$ and a flow rate of 220 $\mathrm{L} / \mathrm{min}$. Scanning electron microscopy analysis showed that as-prepared silver particles were aggregated and had various types of morphologies such as spherical, spheroidal and irregular. The volume average particle size of as-prepared silver powder was $7.7 \mu \mathrm{m}$ at the drain rate of $0.024 \mathrm{~kg} / \mathrm{s}$. The particle size decreased with decreasing the drain rate. Powder X-ray diffraction revealed that the silver powder with a single phase and high crystallinity was formed. Surface treatment of silver powders classified to $5 \mu \mathrm{m}$ was performed at $10,000^{\circ} \mathrm{C}$ by radio-frequency $(\mathrm{RF})$ plasma under argon atmosphere. RF plasma treatment led to the formation of spherical particles from irregular particles. The crystallinity and crystallite of silver powder were increased by RF plasma treatment. X-ray photoelectron spectroscopy showed that the oxygen content in silver particles decreased from $500 \mathrm{ppm}$ to $45 \mathrm{ppm}$. Thermomechanical analysis revealed that the shrinkage of silver powder reduced by the RF plasma treatment. It was clear that the particle characterization of silver powder was significantly modified by RF plasma treatment. The specific resistivity of silver paste sintered at $900^{\circ} \mathrm{C}$ exhibited $1.89 \times 10^{-8} \Omega \mathrm{m}$.
\end{abstract}

\section{Introduction}

So far, silver powder has been used in various industrial applications as electronic devices [1,2]. They are particularly important for electrode material in ceramic capacitor $[3,4]$ and silicon solar cells $[5,6]$. Generally, silver powder has been synthesized for the above applications by chemical reduction method $[7,8]$. In a chemical reduction method, dispersants must be added to starting solution during the chemical reaction to prevent agglomeration of particle after drying. Chemical reduction method is time-consuming and complex process, as there are a number of processes involved, such as chemical reaction, separation, collection, and drying. Also, chemical reduction method has a high environmental-load because a large amount of solvent is discharge.

Therefore, we noted water atomization as an alternative method for production of silver powder $[9,10]$. Atomization is simple process and produces high purity silver powder in a shorter time that a chemical reduction method. The as-prepared silver powder can be used again by recycling. However, atomization often produces irregular particles with particle size larger than $10 \mu \mathrm{m}$ when the water pressure and flow rate are low. In this method, high pressure water breaks up a molten metal stream, which then solidifies into the metal powder. It has been reported [11-15] that uniform and smaller metal powders were formed by controlling conditions such as nozzle type, pressure and water flow rate. So far, the metal powders described above have been produced by atomization under an air atmosphere. The air atmosphere led to the oxidation of metal powder during the atomization [16]. Therefore, in order to improve the particle morphology and reduce the oxygen content, we examined Radio-frequency (RF) plasma treatment of silver particle derived from water atomization. The plasma technology has been applied for formation of nano-particle, thin film and surface modification. RF plasma can melt the silver powder while maintaining high purity because it is different from the method to heat an electrode like arc plasma. In this paper, the particle characterization and sintering property of the surface-treated silver powder were investigated.

\section{Materials and Method}

\section{Powder production and characterization}

Water atomization apparatus [17] consisted of an atomizer nozzle, tundish and melting furnaces, a water tank, and a filter press. Silver products $(99.99 \%)$ which were made using silversmithing method were used as the starting materials. The silver products were placed into graphite crucible in the tundish and melting furnaces and melted at more than $1,300^{\circ} \mathrm{C}$ for $2 \mathrm{~h}$ under a nitrogen atmosphere. The silver products of $25 \mathrm{~kg}$ were melted at once. Molten silver was drained from the tundish nozzle at rate of $0.024 \mathrm{~kg} / \mathrm{s}$ and atomized by water at a pressure of $80 \mathrm{MPa}$ and a water flow rate of $220 \mathrm{~L} / \mathrm{min}$. The drain rate of molten silver ranged from $0.024 \mathrm{~kg} / \mathrm{s}$ to $0.044 \mathrm{~kg} / \mathrm{s}$. Silicon nitride was used as a material of tundish nozzle to keep stable drain condition. After atomizing, the silver powder obtained was stocked in the water tank and introduced to the filter press. The silver powder was then separated from the water by the filter press and dried at $60^{\circ} \mathrm{C}$ for $48 \mathrm{~h}$.

The as-prepared silver powder was classified to a particle size of $5 \mu \mathrm{m}$ using a classifier (Nisshin Engineering, TC-25). The surface treatment of silver powder classified to $5 \mu \mathrm{m}$ was performed by RF plasma apparatus under argon atmosphere. RF plasma apparatus consisted of powder feeder, plasma reactor, chamber, powder collector and aspirator. Silver powder was introduced into plasma reactor using a feeder and heated for $1 \mathrm{~s}$ at $10,000^{\circ} \mathrm{C}$. After heating, silver powder was cooled in a chamber and collected in a powder collector by using the aspirator.

"Corresponding Author: Dr. Takashi Ogihara, Daiken Chemical Sales \& Mfg Co., Ltd, 1-3-3 Technoport, Mikuni-cho, Sakai-shi, Fukui, 913-0038, Japan ; E-mail: ogihara@daiken-chem.co.jp

Citation: Arita S, Ogihara T, Kubo T, Tsubota Y, Ohshita K, et al. (2017) Characterization of Silver Powder Produced through Water Atomization and RF Plasma Treatment. Int J Metall Mater Eng 3: 133. doi: https://doi. org/10.15344/2455-2372/2017/133

Copyright: @ 2017 Arita et al. This is an open-access article distributed under the terms of the Creative Commons Attribution License, which permits unrestricted use, distribution, and reproduction in any medium, provided the original author and source are credited. 
Citation: Arita S, Ogihara T, Kubo T, Tsubota Y, Ohshita K, et al. (2017) Characterization of Silver Powder Produced through Water Atomization and RF Plasma Treatment. Int J Metall Mater Eng 3: 133. doi: https://doi.org/10.15344/2455-2372/2017/133

Page 2 of 5

The particle morphology, microstructure, and agglomeration of the silver powder were observed using a scanning electron microscope (SEM, JEOL, JSM-6510). The volume average particle size $\left(\mathrm{D}_{50}\right)$ and standard deviation of silver powder were determined by a dynamic light scattering method (Nikkiso, MT3300EXII). The specific surface area (SSA) of silver powder was measured using the BET method (Shimadzu, Flow Sorb III 2305). The crystal phase of the as-prepared silver powder was identified using powder X-ray diffraction (XRD, Shimadzu, XRD-6100). The carbon content in silver particles was measured with an electron probe micro analyzer (EPMA, JEOL, JXA-8900RL). The oxygen content in silver particles was measured with a X-ray photoelectron spectrometer microprobe (XPS, Thermo ScientificTM, ESCALABTM Xl+). The silicon content in the silver particles was measured with an inductively coupled plasma optical emission spectrometer (ICP, Horiba ULTIMA 2).

\section{Preparation and characterization of silver paste}

To prepare the silver paste, silver powder classified to $5 \mu \mathrm{m}$ was blended with ethyl cellulose and diethylene glycol monobutyl ether acetate by a three-roller mill. The content ratio of silver powder, ethyl cellulose, and diethylene glycol monobutyl ether acetate was 85:2:13 $\mathrm{wt} \%$. The silver paste was coated on a PET film using a doctor blade and was dried at $100^{\circ} \mathrm{C}$ for $2 \mathrm{~h} .13 \mathrm{~mm} \phi$ of disk was cut from it and sintered from $500^{\circ} \mathrm{C}$ to $900^{\circ} \mathrm{C}$ for $1 \mathrm{~h}$ under an air atmosphere. The microstructure of the silver paste was observed using SEM. The shrinkage of the silver paste was measured using thermomechanical analysis (TMA, Shimadzu, TMA8310). The resistivity of the silver paste was measured using a multi-meter (Mitsubishi, MCP-T360).

\section{Results and Discussion}

\section{Powder characterization}

Particle morphology of the as-prepared silver powder is shown in Figure 1. The drain rate was $0.024 \mathrm{~kg} / \mathrm{s}$. As-prepared silver particles had various morphologies such as a spherical, spheroidal and irregular shape. It was well known that irregular particles often were formed due to the quench during the atomization. It was clear that many spherical particles were produced at high pressure and water flow rate. When water atomization was carried out at both high pressure and flow rate, the molten silver was finely fractured and the particle size of silver powder was reduced. The volume average particle size $\left(D_{50}\right)$ and its standard deviation of as-prepared silver powder were 7.7 $\mu \mathrm{m}$ and $4.1 \mu \mathrm{m}$, respectively. It was found that smaller particle sizes were produced at $80 \mathrm{MPa}$, as has been previously reported [14] for metal powders produced with water atomization. Furthermore, this result suggested that high pressure and flow rate led to the formation of the silver powder with a relatively narrow particle size distribution. The content of impurity in as-prepared silver powder is listed in Table 1. Oxygen content in as-prepared silver powder was $500 \mathrm{ppm}$. It was known $[14,16]$ that metal powder derived from water atomization often exhibited high oxygen content, since the oxygen was taken from the water during the atomization. On the other hands, the carbon and silicon contents in silver particles were $410 \mathrm{ppm}$ and $20 \mathrm{ppm}$ respectively. This resulted in that the carbon in graphite crucible diffused into molten silver during the melting more than $1,300^{\circ} \mathrm{C}$. Low silicon content resulted in that the time which the molten silver passed through the silicon nitride nozzle was very short (few second).

\section{Impact of Concept of Spirituality}

The relationship between atomization rate and particle size is shown in Figure 2. The particle size increased up to $9.4 \mu \mathrm{m}$ when the

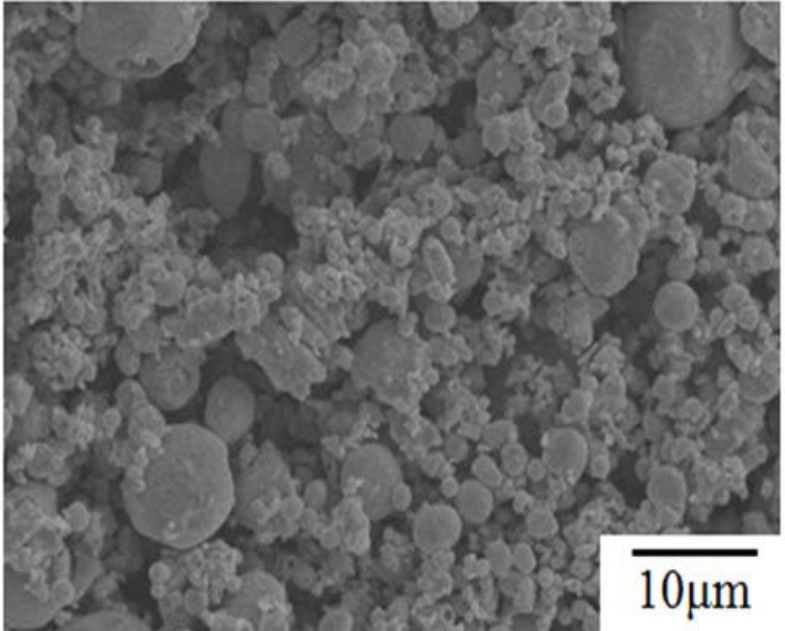

Figure 1: SEM image of as-prepared silver powder.

\begin{tabular}{|l|lll|}
\hline & \multicolumn{3}{|l|}{ Content (ppm) } \\
\hline & $\mathrm{O}$ & $\mathrm{C}$ & $\mathrm{Si}$ \\
\hline As-prepared silver powder & 500 & 410 & 25 \\
\hline
\end{tabular}

Table 1: Content of oxygen, carbon and silicon in as-prepared silver powder.

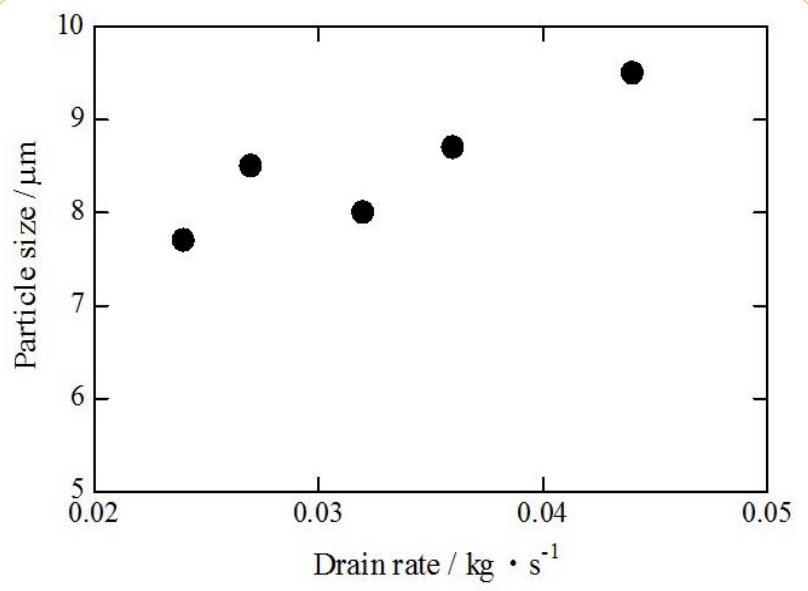

Figure 3: Relationship between production rate and particle size.

drain rate increased to $0.044 \mathrm{~kg} / \mathrm{s}$. This suggested in that the molten silver was not uniformly fractured so that drain rate became high. It was concluded that the lower drain rate was desirable for the production of smaller silver particle. The change of particle size was investigated when the $25 \mathrm{~kg}$ of silver powder was produced repeatedly at 0.024 $\mathrm{kg} / \mathrm{s}$. The relationship between the particle size and production time is shown in Figure 3. It was clear that the fluctuation of $\mathrm{D}_{50}$ was small during the water atomization. This suggested that the stable drain of molten silver was performed from tundish nozzle.

Particle morphology of (a) the silver powder classified to $5 \mu \mathrm{m}$ and (b) the silver powder treated by RF plasma is shown in Figure 4. Irregular particles were still contained in the silver powder classified to $5 \mu \mathrm{m}$. The average particle size of the silver powder was $6.5 \mu \mathrm{m}$. The silver particles exhibited almost spherical morphology by RF plasma treatment. 
Citation: Arita S, Ogihara T, Kubo T, Tsubota Y, Ohshita K, et al. (2017) Characterization of Silver Powder Produced through Water Atomization and RF Plasma Treatment. Int J Metall Mater Eng 3: 133. doi: https://doi.org/10.15344/2455-2372/2017/133

Page 3 of 5

It was found that RF plasma treatment led to formation of uniform spherical particles from irregular particles. Also, the average particle size of the silver powder decreased to $6.0 \mu \mathrm{m}$. It was considered that both sintering and melting were occurred in the silver particles by RF plasma treatment.
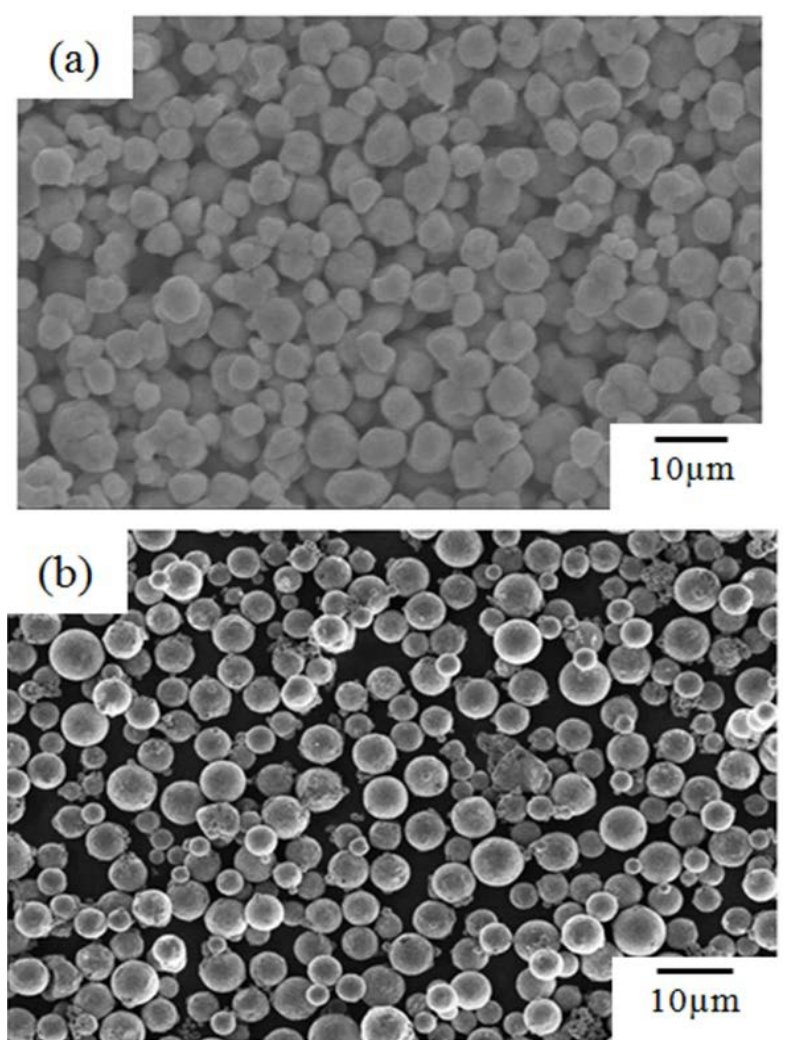

Figure 4: SEM images of (a) silver powder classified to $5 \mu \mathrm{m}$ and (b) silver powder treated by RF plasma .

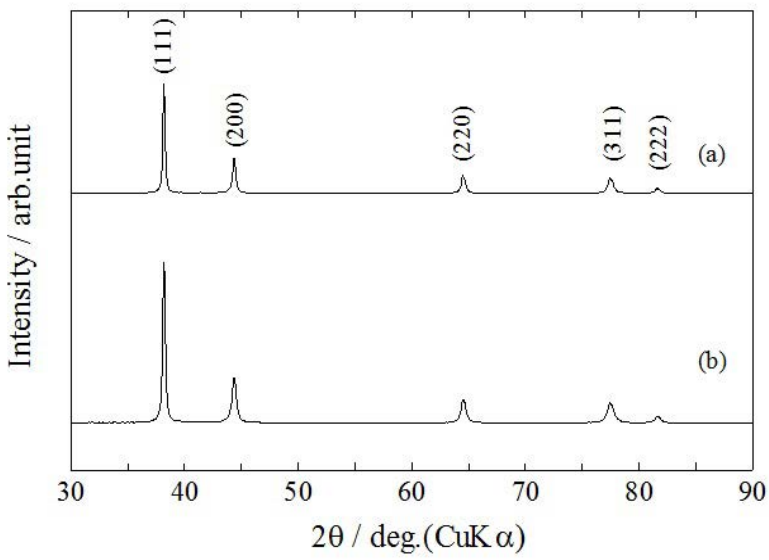

Figure 5: XRD patterns of (a) silver powder classified to $5 \mu \mathrm{m}$ and (b) silver powder treated by RF plasma.

XRD patterns of (a) the silver powder classified to $5 \mu \mathrm{m}$ and (b) the silver powder treated by RF plasma are shown in Figure 5 . The diffraction peaks of them correspond to the reference (JCPDS No.040783) of silver with a high crystallinity. There are no peaks associated with impurity such as silver oxide, carbon, etc. Crystallite size of as-prepared powder was determined from (111) plane by Scherrer equation. The crystallite size of the silver powder classified to $5 \mu \mathrm{m}$ was $7 \mathrm{~nm}$. This suggested that the silver particles consisted of smaller polycrystals. It was considered that the crystallization occurred slowly in spite of rapid quenching. After RF plasma treatment, the crystallite of silver powder was $15 \mathrm{~nm}$. It was found that the growth of polycrystal was occurred by RF plasma treatment. The oxygen content of the silver particles by RF plasma treatment was listed in Table 2. Before RF plasma treatment, the oxygen content in silver particles was $500 \mathrm{ppm}$. After RF plasma treatment, the oxygen content in silver particles decreased from $500 \mathrm{ppm}$ to $45 \mathrm{ppm}$. It was presumed that oxygen ion was released from silver particles by RF plasma treatment.

\begin{tabular}{|l|l|}
\hline \multirow{2}{*}{ Oxygen $(\mathrm{ppm})$} & \multicolumn{2}{|l|}{ Plasma treatment } \\
\cline { 2 - 2 } & before after \\
\hline
\end{tabular}

Table 2: Oxygen content in silver particles by RF plasma treatment.

\section{Sintering and Electrical Properties of Silver Paste}

Figure 6 shows the shrinkage behavior of silver paste measured by TMA. The solid line (a) is the shrinkage curve of silver particles classified to $5 \mu \mathrm{m}$. The dashed line (b) is the shrinkage curve of silver particles treated by RF plasma. The silver paste derived from silver powder classified began to shrink at $380^{\circ} \mathrm{C}$. The shrinkage of silver paste drastically decreased from $600^{\circ} \mathrm{C}$ and reached $12 \%$ at $900^{\circ} \mathrm{C}$. We have been reported that silver powder with a broad particle size distribution generally led to the large shrinkage $[18,19]$. In this work, we considered that the shrinkage of silver paste became large because silver powder classified had a broad particle size distribution. On the other hand, the shrinkage of the silver paste derived from RF plasma treatment began to shrink at $650^{\circ} \mathrm{C}$ and reached $4 \%$ at $900^{\circ} \mathrm{C}$. It was assumed that the silver particles had a high heat-resistance because the silver particles were melted to create the dense surface by RF plasma treatment.

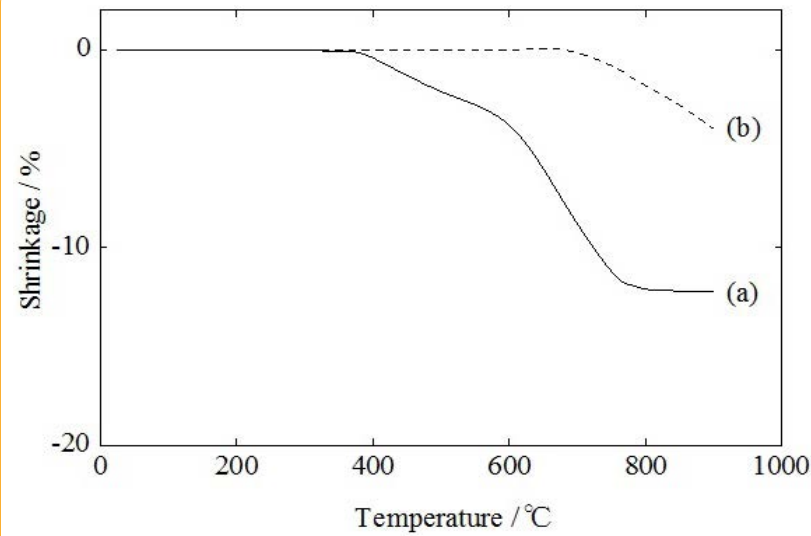

Figure 6: Shrinkage curves of (a) silver powder classified to $5 \mu \mathrm{m}$ and (b) silver powder treated by RF plasma.

Influence of sintering temperature and time in specific resistivity of silver paste was investigated by using the silver powder classified to $5 \mu \mathrm{m}$. Table 3 shows the relationship between sintering temperature and specific resistivity for $600 \mathrm{~s}$ and 3,600 s. The specific resistivity $(\rho)$ was determined by equation (1), where $\mathrm{R}$ is resistivity, $\mathrm{d}$ is the crosssectional area of the electrode and $l$ is the length of the electrode.

$$
\rho=R \times \frac{d}{l}
$$


Citation: Arita S, Ogihara T, Kubo T, Tsubota Y, Ohshita K, et al. (2017) Characterization of Silver Powder Produced through Water Atomization and RF Plasma Treatment. Int J Metall Mater Eng 3: 133. doi: https://doi.org/10.15344/2455-2372/2017/133

Page 4 of 5

\begin{tabular}{|l|lc|}
\hline \multirow{2}{*}{ Sintering time $(\mathrm{s})$} & \multicolumn{2}{|l|}{ Specific resistivity $\left(10^{-8} \Omega \mathrm{m}\right)$} \\
\cline { 2 - 3 } & $700^{\circ} \mathrm{C}$ & $900^{\circ} \mathrm{C}$ \\
\hline 600 & 2.97 & 2.15 \\
\hline 3,600 & 1.94 & 1.89 \\
\hline
\end{tabular}

Table 3: Specific resistivity of silver paste sintered at $700^{\circ} \mathrm{C}$ and $900^{\circ} \mathrm{C}$.

When the sintering time was $600 \mathrm{~s}$, the specific resistivity of the silver paste sintered at $700^{\circ} \mathrm{C}$ and $900^{\circ} \mathrm{C}$ was $2.97 \times 10^{-8} \Omega \mathrm{m}$ and $2.15 \times 10^{-8} \Omega \mathrm{m}$, respectively. The silver paste exhibited low resistivity of the order of $10^{-8} \Omega \mathrm{m}$, which was in agreement with that of the silver paste used for low temperature co-fired ceramics $[19,20]$. When the sintering time was $3,600 \mathrm{~s}$, the specific resistivity of the silver paste sintered at $700^{\circ} \mathrm{C}$ and $900^{\circ} \mathrm{C}$ was $1.94 \times 10^{-8}$ $\Omega \mathrm{m}$ and $1.89 \times 10^{-8} \Omega \mathrm{m}$, respectively. It was confirmed that the silver paste exhibited low specific resistivity so that the sintering temperature was high and sintering time was long.

Figure 7 shows the microstructure of silver paste sintered for 3,600 $\mathrm{s}$ at $700^{\circ} \mathrm{C}$ and $900^{\circ} \mathrm{C}$. The relative density of silver paste ranged from $60 \%$ to $70 \%$ before sintering. SEM image revealed that the open pores were observed in the silver paste sintered at $700^{\circ} \mathrm{C}$. The grain was slightly grown in the silver paste. The relative density of silver paste sintered at $700^{\circ} \mathrm{C}$ ranged from $80 \%$ to $90 \%$. The open pores disappeared and large grain growth was observed in the silver paste sintered at $900^{\circ} \mathrm{C}$. The relative density of silver paste sintered at $900^{\circ} \mathrm{C}$ exhibited more than $90 \%$.
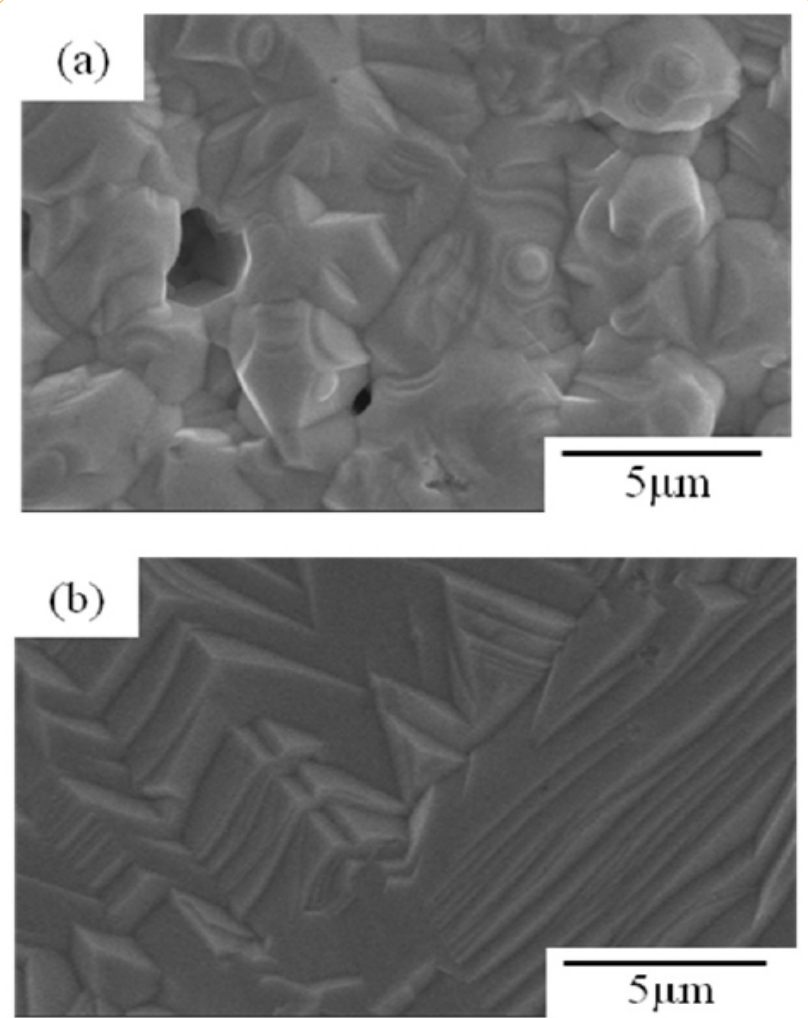

Figure 7: SEM images of silver paste sintered for $3,600 \mathrm{~s}$ at (a) $700^{\circ} \mathrm{C}$ and (b) $900^{\circ} \mathrm{C}$.

It was considered that the specific resistivity of silver paste sintered at $700^{\circ} \mathrm{C}$ was lower than that of silver paste sintered at $900^{\circ} \mathrm{C}$ because of the existence of open pore and undeveloped grain growth in silver paste sintered at $700^{\circ} \mathrm{C}$. We concluded that the difference of specific resistivity between $700^{\circ} \mathrm{C}$ and $900^{\circ} \mathrm{C}$ resulted in the microstructure of silver paste sintered. In this work, we have not evaluated the sinterability and electrical properties of silver powder treated by RF plasma. In future, we will investigate the sinterability and electrical properties of silver paste using silver powder treated by RF plasma.

\section{Conclusions}

A silver powder was produced through water atomization with high water pressure and flow rate. As-prepared silver particles with volume average particle size of $7.7 \mu \mathrm{m}$ were aggregated and had various types of morphologies such as spherical, spheroidal, and irregular. The particle size decreased with decreasing the drain rate. The silver powder had a single phase with high crystallinity and contained oxygen of $500 \mathrm{ppm}$. By RF plasma treatment, the crystallinity and crystallite size increased and oxygen content significantly decreased from $500 \mathrm{ppm}$ to $45 \mathrm{ppm}$. Also, the silver particles exhibited uniform spherical morphology by RF plasma treatment. TMA measurement reveled that the shrinkage of the silver paste decreased from $12 \%$ to $4 \%$ by RF plasma treatment. The specific resistivity of silver paste sintered at $900^{\circ} \mathrm{C}$ for $3,600 \mathrm{~s}$ was $1.89 \times 10^{-8} \Omega \mathrm{m}$.

\section{Competing Interests}

The authors declare that they have no competing interests.

\section{References}

1. Peter PMH, Veit HM, Bemardes AM (2014) Evaluation of gold and silver leaching from printed circuit board of cellphones. Waste Manage 34: 475482.

2. Kim KS, Jung KH, Jung SB (2014) Design and fabrication of screen-printed silver circuits for stretchable electronics. Microelectron Eng 120: 216-220.

3. Bittner A, Seidel H, Schmid U (2011) Electromigration resistance and long term stability of textured silver thin films on LTCC. Microelectron Eng 88: 127-130.

4. Wang Y, Zhang G, Ma J (2002) Research of LTCC/Cu, Ag multilayer substrate in microelectronic packaging. Mater Sci Eng B 94: 48-53.

5. Liu P, Yang SE, Ma Y, Lu X, Jia Y, Ding D, Chen Y (2015) Design of Ag nanograting for broadband absorption enhancement in amorphous silicon thin film solar cells. Mater Sci Semicon Proc 39: 760-763.

6. Tsai JT, Lin ST (2013) Silver powder effectiveness and mechanism of silver paste on silicon solar cells. J Alloy Compd 548:105-109.

7. Chou KS, Ren CY (2000) Synthesis of nanosized silver particles by chemical reduction method. Mater Chem Phys 64: 241-246.

8. An B, Cai XH, Wu FS, Wu YP (2010) Preparation of micro-sized and uniform spherical Ag powders by novel wet-chemical method. Trans Nonferrous Met Soc China 20: 1550- 1554.

9. Ankus AT, Venter RD (1992) The water atomization of silver: Effect of pressure and superheat. Powder Technol 73: 169-179.

10. Kato $Y(2014)$ Industrialization and application of atomized fine powder for PM industry. J Jpn Soc Powder Powder Metall 61: 465-472.

11. Nitta M, Ogura K, Saito $S$, Sugihara $H$ (1992) Atomization of molten iron by annular concentric water jet. Kawasaki Steel Giho 24: 290-295.

12. Bergquist B, Ericsson $T$ (2000) A robustness simulation of water atomization. Powder Metall 43: 37-42.

13. Takeda T, Minagawa K (1991) Water atomizing conditions and properties of spherical iron fines. J Jpn Soc Powder Powder Metall 38: 796-799.

14. Kikukawa M, Matsunaga S, Inaba T, Iwatsu O, Takeda T (2000) Development of spherical fine powders by high-pressure water atomization using swirl water jet. J Jpn Soc Powder Powder Metall 47: 453-457.

15. Endo I, Okuno R, Satake H, Otsuka I, Yamamoto H, et al. (2001) Production of amorphous soft magnetic powders by the new water atomization process "SWAP". J Jpn Soc Powder Powder Metall 48: 697-702. 
Citation: Arita S, Ogihara T, Kubo T, Tsubota Y, Ohshita K, et al. (2017) Characterization of Silver Powder Produced through Water Atomization and RF Plasma Treatment. Int J Metall Mater Eng 3: 133. doi: https://doi.org/10.15344/2455-2372/2017/133

Page 5 of 5

16. Toyoshima H, Shimura T, Watanabe A, Otsu H (2005) Sintered compact properties of Pre-alloyed $2 \% \mathrm{Ni}-\mathrm{Fe}$ water atomized powder. J Jpn Soc Powder Powder Metall 52: 437-441.

17. Ogihara T, Kubo T, Arita S, Aoyagi N, Ueyama R, et al. (2017) Production and characterization of silver powder created using high-pressure water atomization. J Ceram Soc Jpn 125: 19-22.

18. Aoyagi N, Ookawa T, Ueyama R, Ogata N, Ogihara T (2004) Electrical properties of spherical Ag-Pd alloy particles synthesized by ultrasonic spray pyrolysis. J Ceram Soc Jpn 112: S891-894.

19. Okada A, Ogihara T (2010) Sintering behaviour of silver particles in electrode for multilayer ceramic substrate. Key Eng Mater 421: 289-292.

20. Okada A, Ogihara T (2009) The effect of particle size on sintering of conductive silver paste in electrode for LTCC. Trans Mater Res Soc Jpn 34: $121-124$ 